\title{
Krónikus légzőszervi betegek tápláltsági állapotának vizsgálata - klinikai megfigyelések
}

\author{
Fekete Mónika dr. ${ }^{1}$. Pongor Vince dr. ${ }^{1}$. Fehér Ágnes dr. ${ }^{1}$ \\ Veresné Bálint Márta dr. ${ }^{2}$ - Varga János Tamás dr. ${ }^{3}$ - Horváth Ildikó dr. ${ }^{1,3,4}$ \\ 'Semmelweis Egyetem, Általános Orvostudományi Kar, Népegészségtani Intézet, Budapest \\ ${ }^{2}$ Semmelweis Egyetem, Egészségtudományi Kar, Dietetikai és Táplálkozástudományi Tanszék, Budapest \\ ${ }^{3}$ Országos Korányi Pulmonológiai Intézet, Budapest \\ ${ }^{4}$ Emberi Erőforrások Minisztériuma, Egészségügyért Felelős Államtitkárság, Budapest
}

Bevezetés: Krónikus obstruktív légúti betegekben a tápanyagok fokozott felhasználása és a szükséglethez képest alacsonyabb energiabevitel miatt alultápláltság alakulhat ki.

Célkitüzés: Kutatásunk célja volt felmérni a 40 év feletti, krónikus obstruktív tüdőbetegségben (COPD) szenvedő emberek tápláltsági állapotát, valamint megvizsgáltuk az összefüggéseket a betegség súlyossága és a betegek tápláltsági állapota között.

Módszer: Retrospektív obszervációs vizsgálatot végeztünk az Országos Korányi Pulmonológiai Intézet légzésfunkciós laboratóriumában 2017. évben megjelent betegek körében; a légzésfunkciós és antropometriai adatokat az egészségügyi elektronikus nyilvántartási rendszerből nyertük ki. A beválasztási kritériumok a 40 év feletti életkor és a COPD diagnózisa voltak. A légúti obstrukció súlyosságát a mért $\mathrm{FEV}_{1}$-értékek alapján GOLD-stádiumok szerint kategorizáltuk. Eredményeinket SPSS Statistics V22.0 programban dolgoztuk fel.

Eredmények: A betegek átlagéletkora 66 év volt; a nemi megosztást tekintve 49,3\% férfi és 50,7\% nő volt. A COPD-s betegek körében az átlagos testtömegindex (BMI) $27,14 \mathrm{~kg} / \mathrm{m}^{2}$ volt, értéke széles tartományban mozgott: a cachexia, valamint a súlyos obesitas egyaránt előfordult. A FEV $($ ref\%)-értékek alapján a 3236 vizsgált beteget GOLD I.: 30\%, GOLD II.: 40\%, GOLD III.: 23\% és GOLD IV.: 7\% stádiumba soroltuk be. Pozitív korrelációt találtunk a mért $\mathrm{FEV}_{1}$-értékek és a tápláltsági állapot között $(\mathrm{H}=0,2297, \mathrm{r}=0,1401)$, azaz a cachexia mértéke a betegség súlyosságával összefüggést mutatott. Varianciaanalízis alapján szignifikáns összefüggést találtunk a betegek tápláltsági állapota és a betegség súlyossága között $(\mathrm{p}<0,001)$, azaz a magasabb BMI-vel rendelkező betegek jobb tüdőfunkcióval rendelkeztek.

Következtetés: A malnutritio kedvezőtlen hatású a légzésfunkcióra, gyengül a légzőizmok teljesítménye. Vizsgálatunkban a BMI növekedésével a $\mathrm{FEV}_{1}$-értékek javultak, tehát a BMI hasznos mutató lehet a COPD-s betegek légzésfunkciós prognózisának előrejelzésében.

Orv Hetil. 2019; 160(23): 908-913.

Kulcsszavak: COPD, BMI, GOLD-stádium, tápláltsági állapot

\section{Relationship of chronic obstructive pulmonary disease and nutritional status - clinical observations}

Introduction: The increased metabolism of nutrients and the low energy intake may lead to malnutrition among chronic obstructive pulmonary disease (COPD) patients.

Aim: The goal of our study was to examine the nutritional status of our population aged over 40 , and its relationship with the severity of the disease.

Method: We conducted a retrospective study at the National Korányi Institute of Pulmonology in 2017. Pulmonary function and anthropometric data were obtained from the electronic health record system. Inclusion criteria were age over 40 and the diagnosis of COPD. Severity of disease was assessed by forced expiration volume and categorized according to GOLD stages. We used SPSS Statistics V22.0 for data analysis.

Results: The mean age of participants was $66 ; 49.3 \%$ were men, $50.7 \%$ were women. Average BMI was $27.14 \mathrm{~kg} / \mathrm{m}^{2}$, with values comprising cachexia and severe obesity. According to the $\mathrm{FEV}_{1} \%$ pred results of the 3236 patients, $30 \%$ 
fell in the GOLD I, 40\% in the GOLD II, 23\% in the GOLD III, and 7\% in the GOLD IV categories. Pearson coefficient found positive correlation between $\mathrm{FEV}_{1}$ and nutritional status $(\mathrm{H}=0.2297, \mathrm{r}=0.1401)$, specifically between severity of cachexia and severity of disease. The analysis of variance showed significant correlation between severity of disease and nutritional status; patients with higher BMI had better pulmonary function.

Conclusion: Malnutrition had an adverse effect on pulmonary functions and performance of respiratory muscles, whereas higher BMI had a positive effect on $\mathrm{FEV}_{1}$. Our results suggest that BMI could be used as a lung function prognostic indicator for COPD patients.

Keywords: COPD, BMI, GOLD stages, nutritional status

Fekete M, Pongor V, Fehér Á, Veresné Bálint M, Varga JT, Horváth I. [Relationship of chronic obstructive pulmonary disease and nutritional status - clinical observations]. Orv Hetil. 2019; 160(23): 908-913.

(Beérkezett: 2018. december 12.; elfogadva: 2019. január 27.)

\begin{abstract}
Rövidítések
ANOVA $=($ analysis of variance $)$ varianciaanalízis; $\mathrm{BMI}=($ body mass index) testtömegindex; $\mathrm{BNO}=$ Betegségek Nemzetközi Osztályozása; COPD = (chronic obstructive pulmonary disease) krónikus obstruktív tüdőbetegség; EHR = (electronic health record) egészségügyi eletronikus nyilvántartási rendszer; $\mathrm{FEV}_{1}=$ (forced vital capacity in 1 second $)$ eróltetett kilégzés első másodperctérfogata; FFMI = (fat-free mass index $)$ zsírmentes testtömegindex; FVC $=$ (forced vital capacity) erőltetett kilégzési vitálkapacitás; GOLD = (Global Initiative for Chronic Obstructive Lung Disease) nemzetközi COPD-ajánlás; WHO $=($ World Health Organization) Egészségügyi Világszervezet
\end{abstract}

A krónikus obstruktív tüdóbetegség (COPD) jelentős népegészségügyi problémát jelent világszerte $[1]$; morbiditása a felnőtt lakosság legalább 6\%-át érinti, és becslések szerint 2030-ra a harmadik leggyakoribb halálok lehet $[1,2]$. A légúti áramlási ellenállás-fokozódás a tüdő - szövetkárosító gázok és részecskék inhalációjának (leginkább a dohányzás) hatására kialakuló - kórosan fokozott gyulladásos reakciójának következménye [3]. A kórkép akut állapotrosszabbodásai (exacerbatiói) és társbetegségei, mint például a cardiovascularis rendszert vagy az anyagcserét érintô betegségek meghatározó prognosztikai összetevői a COPD súlyosságának [4].

$\mathrm{Az}$ alacsony testtömegindex (BMI) és a COPD-ben szenvedő betegek rossz prognózisa közötti összefüggés gyakori klinikai megfigyelés, prognosztikai értéke évtizedek óta érdeklődés tárgyát képezi. Ezen faktor fokozott kockázatot jelent a súlyos obstruktív tüdőbetegség kialakulásában, azonban nem világos, hogy a hatás független-e más prognosztikai tényező́któl [5]. Az alacsony BMI a COPD-ben szenvedő betegek túlélésének független negatív meghatározó tényezője; kialakulásának okai között szerepelhet az étvágytalanság, az infekció, a gyógyszermellékhatás (antibiotikumok, teofillin, xantinszármazékok), az evést akadályozó légszomj, a légzési elégtelenség okozta felszívódási zavar, a depresszió, de akár a kórházi környezet hatása is közrejátszhat a kialakulásában $[6,7]$.
A jelen vizsgálatot azzal a céllal végeztük, hogy értékeljük a COPD-s betegek táplálkozási statusát, és korrelációt keressünk a COPD súlyossága (GOLD-stádiuma) és a betegek tápláltsági állapota (BMI) között.

\section{Módszer}

Retrospektív obszervációs vizsgálatot végeztünk az Országos Korányi Pulmonológiai Intézet légzésfunkciós laboratóriumában 2017. évben megjelent betegek körében; a betegek antropometriai, valamint légzésfunkciós adatait elektronikus egészségügyi nyilvántartási (electronic health record - EHR) rendszer használatával kaptuk. Beválasztási kritérium volt a 40 év feletti életkorú COPD-s beteg.

Az alultápláltság/obesitas előfordulási gyakoriságának megítélésére a testtömegindexet (body mass index BMI) használtuk, a betegeket a WHO-klasszifikáció szerinti testtömeg-kategóriákba soroltuk (1. táblázat). A testtömegindexet a testtömeg $(\mathrm{kg})$ és a testmagasság négyzetének $\left(\mathrm{m}^{2}\right)$ hányadosával számoltuk ki.

A légúti obstrukció súlyosságát a mért postbronchodilator (hörgtágítás utáni) $\mathrm{FEV}_{\mathrm{1}^{-}}$(erôltetett kilégzés első másodperctérfogata) értékek alapján a nemzetközi COPD-ajánlás (GOLD - Global Initiative for Chronic

1. táblázat |A WHO szerinti testtömegindex-kategóriák

\begin{tabular}{ll}
\hline BMI-érték $\left(\mathrm{kg} / \mathrm{m}^{2}\right)$ & Kategória \\
\hline$<16$ & súlyos soványság \\
$16-16,99$ & mérsékelt soványság \\
$17-18,49$ & enyhe soványság \\
$18,5-24,99$ & normál testsúly \\
$25-29,99$ & Túlsúlyos \\
$30-34,99$ & I. fokú elhízás \\
$35-39,99$ & II. fokú elhízás \\
$\geq 40$ & III. fokú (súlyos) elhízás \\
\hline
\end{tabular}


Obstructive Lung Disease) légzésfunkciós stádiumai szerint kategorizáltuk. A spirometriás mérést hörgtágító inhalációja (400 $\mu \mathrm{g}$ szalbutamol) után értékeltük. A légúti obstrukció fennállásának diagnózisát mint „diagnosztikus küszöb” a $\mathrm{FEV}_{1} / \mathrm{FVC}$ (az erőltetett kilégzés első másodperctérfogata és az erőltetett kilégzési vitálkapacitás hányadosa) $<70 \%$ alapján állítottuk fel.

Az I. súlyossági csoportba (GOLD I.) kerültek az enyhe COPD-s betegek, akiknél a mért postbronchodilator $\mathrm{FEV}_{1}$ magasabb volt, mint $80 \mathrm{ref} \%$. A II. súlyossági csoportba (GOLD II.) soroltuk a közepesen súlyos COPD-s betegeket, akiknél a mért $\mathrm{FEV}_{1} 50$ és 80 ref\% közé esett, míg a III. súlyossági kategóriába (GOLD III.) a súlyos COPD-s betegeket, akiknél a mért $\mathrm{FEV}_{1} 30$ és 50 ref\% közé esett. A IV. súlyossági csoportba (GOLD IV.) a nagyon súlyos COPD-s betegek kerültek, akiknél a mért postbronchodilator $\mathrm{FEV}_{1}$ alacsonyabb volt, mint $30 \mathrm{ref} \%$.

A feldolgozást és elemzést az SPSS 22.0 programmal (IBM Corporation, Armonk, NY, Amerikai Egyesült Államok) készítettük. A leíró statisztikai módszerek közül Pearson-féle $\chi^{2}$-próbát és egy szempontos varianciaanalízist (ANOVA) végeztünk. Az eredményeket $\mathrm{p}<0,05$ érték esetén tekintettük szignifikánsnak.

\section{Eredmények}

Összességében 3236 COPD-s beteg légzésfunkciós és antropometriai adatait tekintettük át, mintánkban 1596 férfi $(49,32 \%)$ és 1640 (50,68\%) nő szerepelt. A vizsgált populáció átlagéletkora: 66,18 év $(S D \pm 9,96)$ volt; a 40-96 éves COPD-s betegek szerepeltek a vizsgálatban, a leggyakoribb korcsoportok a 60-69 évesek és a 70-79 évesek közül kerültek ki. A betegek korcsoportos megoszlását az 1. ábra mutatja. A férfiak átlagéletkora 66,27 év, míg a nőké 66,09 év volt. A betegek diagnózisa (BNO-kód) alapján COPD és COPD akut exacerbatio miatti jelentkezés fele-fele arányban történt a légzésfunkciós laborban.

Az Egészségügyi Világszervezet (WHO) standardja szerint minden résztvevő esetében testtömeg-kategóriákba sorolást végeztünk a BMI alapján, így nyolc alcsoportba kerültek COPD-s betegeink (1. táblázat). A vizsgált populációban légútikorlátozottság-súlyossági besorolást végeztünk a hörgtágítás utáni $\mathrm{FEV}_{1}$ (ref\%)-értékek alapján a GOLD-stádiumoknak megfelelően; ennek lényege a légzésfunkciós értékeken alapuló súlyossági beosztás, és meghatározza a betegek gyógyszeres kezelésé-

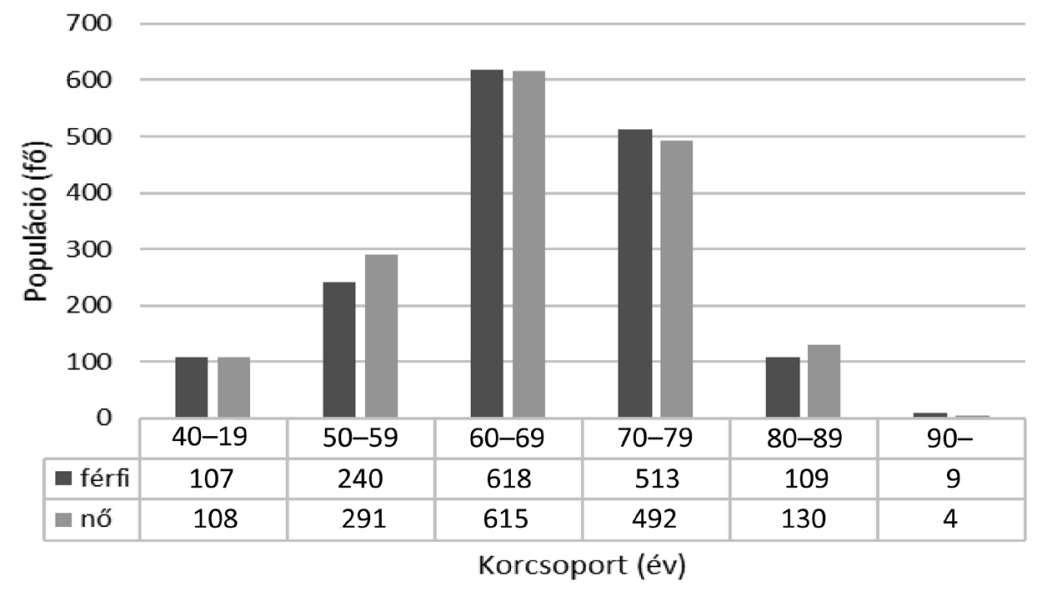

1. ábra

| A vizsgált populáció korcsoportos megoszlása $(\mathrm{n}=3236)$

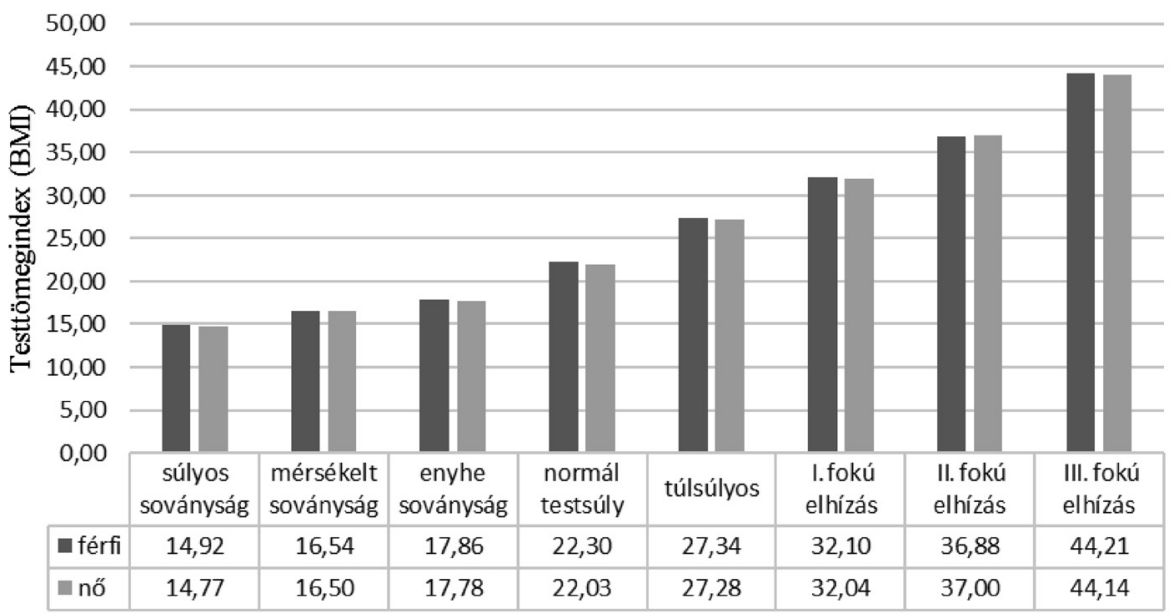




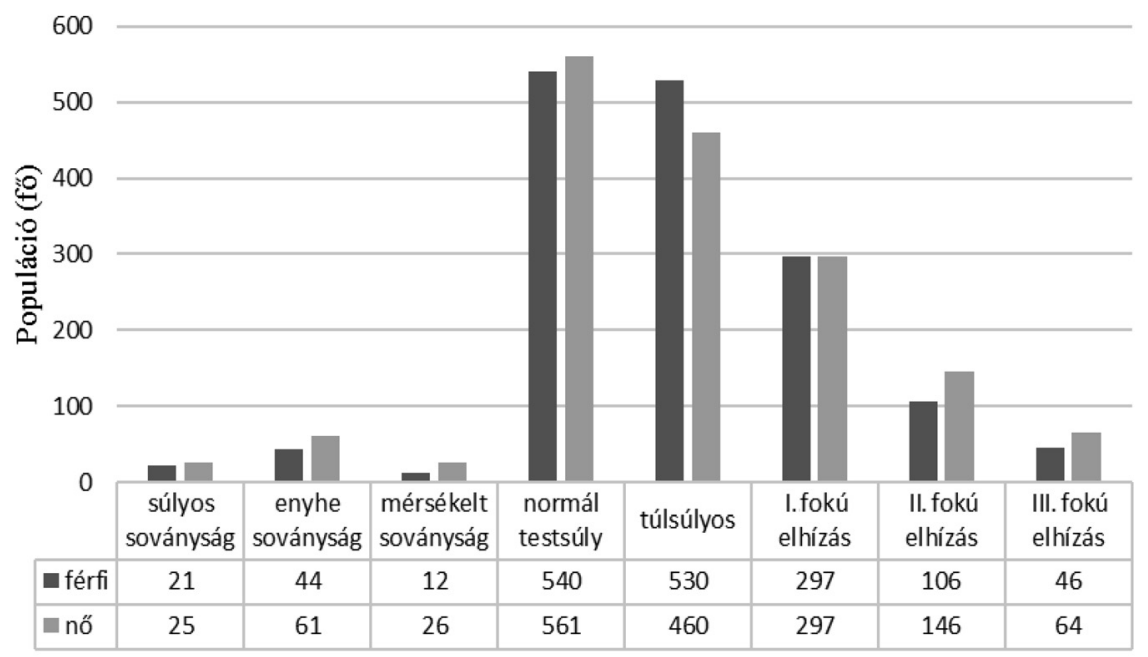

3. ábra

| A teljes populáció megoszlása a testtömegindex alapján $(\mathrm{n}=3236)$

nek standardjait. Eszerint a postbronchodilator $\mathrm{FEV}_{\mathrm{l}} /$ FVC $<70 \%$ értékü betegek esetében GOLD I.: enyhe $\left(\mathrm{FEV}_{1}>80\right.$ ref\%), GOLD II.: közepesen súlyos (50-80 ref\% $\left.\mathrm{FEV}_{\mathrm{l}}\right)$, GOLD III.: súlyos (30-50 ref\% $\left.\mathrm{FEV}_{1}\right)$ és GOLD IV.: nagyon súlyos $\left(\mathrm{FEV}_{1}<30 \mathrm{ref} \%\right)$ kategóriákat alkottunk.

A betegek átlagos BMI-je 27,14 volt, a férfiaké 27,13, míg a nőké 27,15; a BMI-átlagok nemek szerinti megoszlását a 2. ábra mutatja. A testtömegindex-átlagok a különböző súlyossági fokozatokban a következők voltak: GOLD I.: $27,57 \mathrm{~kg} / \mathrm{m}^{2}$, GOLD II.: $28,00 \mathrm{~kg} / \mathrm{m}^{2}$, GOLD III.: $26,26 \mathrm{~kg} / \mathrm{m}^{2}$ és GOLD IV.: $23,13 \mathrm{~kg} / \mathrm{m}^{2}$.

Normál testsúlyú volt a vizsgált populáció egyharmada $(\mathrm{n}=1101)$, alultáplált $\left(\mathrm{BMI}<18,49 \mathrm{~kg} / \mathrm{m}^{2}\right)$ a betegek $5,83 \%$-a $(\mathrm{n}=189)$. A túlsúlyos $\left(\mathrm{BMI}>24,99 \mathrm{~kg} / \mathrm{m}^{2}\right) \mathrm{ka}-$ tegóriába került a betegek több mint fele $(56,74 \%)$, és súlyos fokban elhízott $\left(\mathrm{BMI}>40 \mathrm{~kg} / \mathrm{m}^{2}\right)$ volt a betegek $3,40 \%-\mathrm{a}(\mathrm{n}=110)$. A teljes populáció megoszlását a BMI alapján a 3. ábra mutatja.

A 3236 fó beteg közül GOLD I-es stádiumba soroltuk a betegek egyharmadát $(30,41 \%)$, GOLD II-es stádiumba a betegek $40 \%$-át, GOLD III-as stádiumba a betegek egynegyedét $(22,65 \%)$ és GOLD IV-es kategóriába a betegek csaknem 7\%-át. A mért hörgtágítás utáni $\mathrm{FEV}_{1}$ (ref\%)-átlagok a súlyossági kategóriáknak megfelelően a következők voltak: GOLD I.: 97,09\%, GOLD II.: 64,22\%, GOLD III.: 40,02\%, valamint GOLD IV.: 23,66\%. Teljes körü adatainkat a 2. (összefoglaló) táblázat tartalmazza.

Pearson-féle korrelációs együtthatóval pozitív korrelációt találtunk a mért $\mathrm{FEV}_{1}(\mathrm{ref} \%)$-értékek és a tápláltsági állapot (BMI) között $(\mathrm{H}=0,2297, \mathrm{r}=0,1401, \mathrm{p}<0,05)$, azaz a BMI növekedésével a tüdő funkciója jelentősen javult. Egy szempontos varianciaanalízis (ANOVA) alkalmazásával megállapítottuk, hogy a betegek tápláltsági állapota (BMI) a betegség súlyosságával (GOLD) csökkent, és statisztikailag szignifikáns volt $(\mathrm{F}=2,0124$, $\mathrm{p}<0,001)$, azaz az alacsonyabb BMI-vel rendelkező be- tegek rosszabb tüdőfunkcióval rendelkeztek, mint a jobb tápláltsági állapotban lévő COPD-sek. Ez az összefüggés mindkét nemnél beigazolódott (4. ábra).

\section{Megbeszélés}

Tanulmányunkban részletesen ismertettük a 40 év feletti COPD-s betegek tápláltsági állapotának eloszlását a WHO szerinti BMI-kategóriák használatával, és elemeztük a BMI-nek a betegség súlyosságával való kapcsolatát; láthattuk, hogy a malnutritio kedvezőtlen hatású a légzésfunkcióra.

A tápláltsági állapot fontos tényezője a krónikus obstruktív tüdőbetegség kifejlődésének. Kimutatták, hogy a kór előrehaladtával a COPD-ben szenvedő betegekre és különösen a súlyos betegekre nézve veszélyt jelent az alultápláltság, mely azt a lehetőséget rejti magában, hogy a korai beavatkozás alacsony BMI-vel rendelkező betegekben csökkentheti a betegség kifejlődését [8,9]. Cochrane-adatbázisban szereplő metaanalízis alapján elmondható, hogy összefüggés észlelhető az alultápláltság és a súlyos tüdőfunkció között COPD-ben [10], ezért szeretnénk hangsúlyozni, hogy sürgősen szükség van a súlyos COPD-ben szenvedő betegek megfelelő táplálkozási tanácsadására. Bebizonyosodott, hogy az alacsony BMI a súlyos betegek körében a halálozás független kockázati tényezője [11].

Az alultápláltság általános következményei lehetnek: romlik a szervezet védekezőképessége, csökken a légzőizmok ereje, csökken a vitálkapacitás, romlik a gázcsere, a vesében csökken a filtráció, a bélfal sorvadása további felszívódási és emésztési zavarokhoz vezethet $[6,7,12]$. A testsúly növelése javítja a légzőizmok teljesítményét, az erősebb légzőizmok csökkenthetik az akut exacerbatiók lehetőségét, a ventilációt és a terhelhetőséget [1215], ezért az alultáplált COPD-s betegek minél korábbi táplálásterápiájának elkezdése indokolt, melyben javasolt 


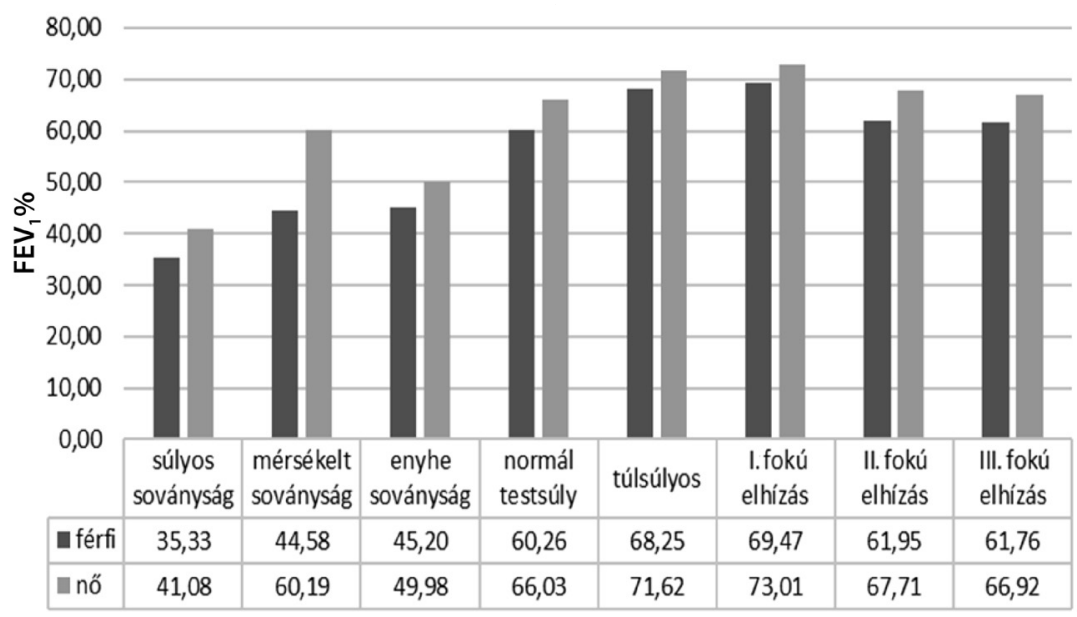

4. ábra | Férfiak és nők erőltetett kilégzési másodperctérfogata $\left(\mathrm{FEV}_{1} \%\right)$ a testtömegindex függvényében $(\mathrm{n}=3236)$

2. táblázat | Összefoglaló táblázat a demográfiai és funkcionális adatokról

\begin{tabular}{|c|c|c|c|c|c|c|c|c|c|}
\hline Életkor (40-96 év) & $\begin{array}{l}\text { Átlagélekor } \\
\text { (év) }\end{array}$ & Fő & $\%$ & & & & & & \\
\hline Férfi & 66,27 & 1596 & 49,32 & & & & & & \\
\hline Nő & 66,09 & 1640 & 50,68 & & & & & & \\
\hline Teljes populáció & 66,18 & 3236 & 100,00 & & & & & & \\
\hline \multicolumn{10}{|l|}{ Légzésfunkció } \\
\hline $\mathrm{FEV}_{1}(\mathrm{ref} \%)$ & 65,99 & & & & & & & & \\
\hline Férfi (\%) & 63,95 & & & & & & & & \\
\hline \multirow[t]{2}{*}{ Nő (\%) } & 67,98 & & & & & & & & \\
\hline & Férfi (fö) & Férfi (\%) & Nő (fö) & Nö (\%) & Összesen (n) & Összesen (\%) & Férfi & Nó & $\mathrm{FEV}_{1}$ ref\% \\
\hline GOLD I. & 447 & 13,81 & 537 & 16,59 & 984 & 30,41 & 95,76 & 98,19 & 97,09 \\
\hline GOLD II. & 633 & 19,56 & 666 & 20,58 & 1299 & 40,14 & 64,29 & 64,17 & 64,22 \\
\hline GOLD III. & 390 & 12,05 & 343 & 10,6 & 733 & 22,65 & 39,92 & 40,13 & 40,02 \\
\hline GOLD IV. & 126 & 3,89 & 94 & 2,9 & 220 & 6,8 & 23,44 & 23,97 & 23,66 \\
\hline SUM & 1596 & 49,32 & 1640 & 50,68 & 3236 & 100,00 & 63,92 & 67,98 & 65,98 \\
\hline \multicolumn{10}{|c|}{ Testtömegindex $(\mathrm{BMI})\left(\mathrm{kg} / \mathrm{m}^{2}\right)$} \\
\hline & Férfi (fö) & Férfi (\%) & Nő (fö) & Nó (\%) & Összesen $(\mathrm{n})$ & Összesen (\%) & Férfi & Nó & $\bar{X}$ \\
\hline$<16$ & 21 & 0,65 & 25 & 0,77 & 46 & 1,42 & 14,92 & 14,77 & 14,83 \\
\hline $16-16,99$ & 12 & 0,37 & 26 & 0,8 & 38 & 1,17 & 16,54 & 16,5 & 16,51 \\
\hline $17-18,49$ & 44 & 1,36 & 61 & 1,89 & 105 & 3,24 & 17,86 & 17,78 & 17,82 \\
\hline $18,5-24,99$ & 540 & 16,69 & 561 & 17,34 & 1101 & 34,02 & 22,3 & 22,03 & 22,16 \\
\hline $25-29,99$ & 530 & 16,38 & 460 & 14,22 & 990 & 30,59 & 27,34 & 27,28 & 27,31 \\
\hline $30-34,99$ & 297 & 9,18 & 297 & 9,18 & 594 & 18,36 & 32,1 & 32,04 & 32,07 \\
\hline $35-39,99$ & 106 & 3,28 & 146 & 4,51 & 252 & 7,79 & 36,88 & 37 & 36,95 \\
\hline$\geq 40$ & 46 & 1,42 & 64 & 1,98 & 110 & 3,4 & 44,21 & 44,14 & 44,17 \\
\hline SUM & 1596 & 49,32 & 1640 & 50,68 & 3236 & 100,00 & 27,13 & 27,15 & 27,14 \\
\hline
\end{tabular}

a magas kalóriatartalmú, fehérjedús táplálék fogyasztása $[2,6,7]$.

Egy Cao és mtsai által végzett metaanalízis azt mutatta, hogy a COPD-ben szenvedő túlsúlyos és elhízott betegek körében alacsonyabb a mortalitás kockázata [16, 17]. Ez a jelenség az úgynevezett „elhízásparadoxon”, amelyet a túlélés és az elhízás közötti inverz összefüggésként definiálunk, és számos krónikus betegségben, köztük a II. típusú diabetes mellitusban [18], stroke-ban [19] és krónikus vesebetegségben is megfigyelték [20]. Ezen megfigyelést saját kutatásunk is támogatja, amely szerint a BMI emelkedésével a $\mathrm{FEV}_{1} \%$-értékek javulnak, azaz a tápláltsági állapot javítása növeli a légzési tartalékot, azonban a testtömegindex növekedése 30-as BMI felett már nem funkcionál védelmi tényezőként. Szakmai ajánlás alapján a 30-nál magasabb BMI esetén a testsúly csökkentése ajánlott, míg a 21-nél alacsonyabb BMI táplálásterápiát indokol. Az orális táplálékfelvétel emelése mellett 
nagy energiatartalmú tápszerekkel lehet/kell a diétát kiegészíteni, és a mellette alkalmazott terheléses tréning fokozza a táplálásterápia hatását $[2,21]$. Azonban a BMI önmagában nem elég, figyelembe kell venni a zsírmentes testtömegindexet (fat-free mass index - FFMI) és a testösszetétel szerepét is a COPD-ben szenvedő betegeknél. A nemzetközi tanulmányok és jelen adataink is megerősítik azon megfigyeléseket, melyek arra utalnak, hogy a COPD-s betegek tápláltsági állapota a betegség stratifikációjának egyik fontos tényezője lehet.

\section{Következtetés}

Jelen klinikai megfigyelésünk során a vizsgálatba bevont betegek egyharmadát normál súlyúnak, több mint felét túlsúlyosnak észleltük, és a betegek alacsony aránya $(5,83 \%-\mathrm{a})(\mathrm{n}=189)$ volt alultáplált. A klinikai adatok alapján a malnutritio kedvezőtlen hatását észleltük a légzésfunkcióra.

Anyagi támogatás: A közlemény megírása és a kapcsolódó kutatómunka anyagi támogatásban nem részesült.

Szerzői munkamegosztás: F. M.: A kézirat megszövegezése, a szakirodalom feldolgozása, részvétel a vizsgálat lefolytatásában. P. V.: A kézirat fordítása, szakirodalomkutatás. F. Á.: Táblázatok, ábrák elkészítése, adatok elemzése. V. B. M.: A statisztikai elemzések elkészítése, szakirodalom-kutatás, részvétel a vizsgálat lefolytatásában. V. J. T.: A kézirat megszövegezése, revíziója, a szakirodalom feldolgozása. H. I.: A vizsgálat tervezése, irányítása, adatfelvétel, a statisztikai elemzések ellenőrzése. A cikk végleges változatát valamennyi szerző elolvasta és jóváhagyta.

Érdekeltség: A szerzőknek nincsenek érdekeltségeik.

\section{Köszönetnyilvánítás}

A szerzők ezúton fejezik ki köszönetüket $d r$. Pákó Juditnak és Tisza Juditnak a vizsgálat lebonyolításának támogatásáért és lelkiismeretes munkájukért.

\section{Irodalom}

[1] Kovács G. An underrated public health issue. [Egy alábecsült népbetegség.] Orvostovábbk Szle. 2015; 22: 8-9. [Hungarian]

[2] World Health Organization. World Health Statistics 2011. Geneva, 2011. Available from: http://www.who.int/whosis/ whostat/EN_WHS2011_Full.pdf [accessed: December 11, 2018].

[3] Böszörményi NGy, Balikó Z, Kovács G, et al. Diagnostic and therapeutic protocols of chronic lung diseases (chronic obstructive pulmonary disease - COPD) in the primary, secondary and emergency health care. [Egészségügyi szakmai irányelv a krónikus tüdőbetegség (COPD) diagnosztikájáról és kezelésérôl, az alap-, szak-, és sürgősségi ellátás területére.] Med Thor. 2014; 67: 76-112. [Hungarian]
[4] Pákó J, Veres D, Tisza J, et al. COPD in the light of multimorbidity. [A COPD a multimorbiditás tükrében.] Orvostovábbk Szle. 2016; 22: 38-43. [Hungarian]

[5] Harik-Khan RI, Fleg JL, Wise RA. Body mass index and the risk of COPD. Chest 2002; 121: 370-376.

[6] Benton MJ, Wagner CL, Alexander JL. Relationship between body mass index, nutrition, strength, and function in elderly individuals with chronic obstructive pulmonary disease. J Cardiopulm Rehabil Prev. 2010; 30: 260-263.

[7] Ezzell L, Jensen GL. Malnutrition in chronic obstructive pulmonary disease. Am J Clin Nutr. 2000; 72: 1415-1416.

[8] Rutten E, Wouters E, Franssen F. Malnutrition and obesity in COPD. Eur Respir Mon. 2013; 59: 80-92.

[9] Global Initiative for Chronic Obstructive Lung Disease. Global Strategy for the Diagnosis, Management and Prevention of Chronic Obstructive Pulmonary Disease (2018 Report). Available from: https://goldcopd.org/wp-content/uploads/2017/ 11/GOLD-2018-v6.0-FINAL-revised-20-Nov_WMS.pdf [December 11, 2018].

[10] Cochrane WJ, Afolabi OA. Investigation into the nutritional status, dietary intake and smoking habits of patients with chronic obstructive pulmonary disease. J Hum Nutr Diet. 2004; 17: 3-11.

[11] Landbo C, Prescott E, Lange P, et al. Prognostic value of nutritional status in chronic obstructive pulmonary disease. Am J Respir Crit Care Med. 1999; 160: 1856-1861.

[12] Vanfleteren LE, Spruit MA, Wouters EF, et al. Management of chronic obstructive pulmonary disease beyond the lungs. Lancet Respir Med. 2016; 4: 911-924.

[13] Skyba P, Kluchova Z, Joppa P, et al. Nutritional status in relation to respiratory impairment and systemic inflammation in patients with acute exacerbations of COPD. Med Sci Monit. 2009; 15: CR528-CR533.

[14] Somfay A. Coughing, suffocation - am I suffering from COPD? [Fulladok, köhögök - COPD-s vagyok?] SpringMed Kiadó, Budapest, 2005. [Hungarian]

[15] Varga J, Munkácsi A, Máthé Cs, et al. The effect of the inspiratory muscles training on physical condition in COPD. [A belégző izmok tréningjének hatása a betegek fizikai állapotára COPDben.] Med Thor. 2018; 71: 96-102. [Hungarian]

[16] Cao C, Wang R, Wang JM, et al. Body mass index and mortality in chronic obstructive pulmonary disease: a meta-analysis. PLoS ONE 2012; 7: e43892.

[17] Stoll P, Foerster S, Virchow JC. Overweight is a predictor of long-term survival in hospitalized patients with exacerbations of COPD. Respir Med. 2016; 116: 59-62.

[18] Liu XM, Liu YJ, Zhan J, et al. Overweight, obesity and risk of all-cause and cardiovascular mortality in patients with type 2 diabetes mellitus: a dose-response meta-analysis of prospective cohort studies. Eur J Epidemiol. 2015; 30: 35-45.

[19] Bagheri M, Speakman JR, Shabbidar S, et al. A dose-response meta-analysis of the impact of body mass index on stroke and all-cause mortality in stroke patients: a paradox within a paradox. Obes Rev. 2015; 16: 416-423.

[20] Kovesdy CP, Anderson JE, Kalantar-Zadeh K. Paradoxical association between body mass index and mortality in men with CKD not yet on dialysis. Am J Kidney Dis. 2007; 49: 581-591.

[21] Varga J. Chronic obstructive pulmonary disease. [Krónikus obstruktív tüdóbetegség.] Háziorv Továbbk Szle. 2018; 23: 2630. [Hungarian]

(Fekete Mónika dr., Budapest, Túzoltó utca 80. 5/46, 1094 e-mail: fekete.monika@med.semmelweis-univ.hu) 